\title{
John Crowley Named Editor of C\&RL News
}

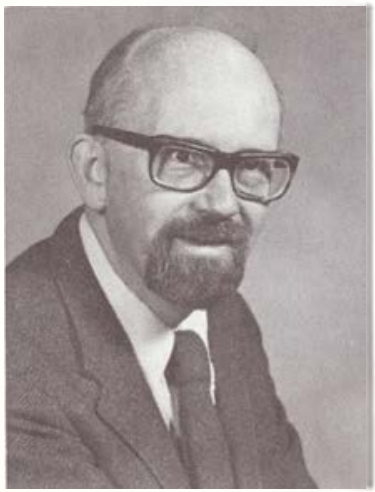

John V. Crowley

John V. Crowley has been appointed editor of C\&RL News beginning with the January 1977 issue. The new editor, who is assistant director of libraries at Milne Library, State University College, Oneonta, New York, succeeds Mary Frances Collins of the State University of New York at Albany.

To our readers:

As we retire from the editorship of College and Research Libraries News, we wish to give special thanks to Eileen Mahoney and her staff at the Central Production Unit of ALA Headquarters. The infinite patience and helpfulness of the dedicated staff at CPU has made our job of editing the News possible and often rewarding. We also wish to thank Richard Johnson, editor of $C \mho R L$, for the opportunity to work with him serving the membership of ACRL. Particular thanks also go to Eleanor Bulson, our secretary at State University of New York, Albany, who has given us so much help in the preparation of each issue of $C \triangleleft R L$ News.

Mary Frances Collins and Anne Dowling, Editors, CURL News
Mr. Crowley has been with Milne Library for the past eleven years, first serving as coordinator of technical services, then as overall coordinator of services. He also served as acting director in 1972-73. He was recently promoted to the rank of librarian.

Previous to his association with Milne Library, he taught high school English, was a school librarian, and then became catalog librarian at State University College, Cortland, New York. Subsequently, he was photo librarian at the Department of School Services and Publications, Wesleyan University, Connecticut, and reference librarian at Worcester State College, Massachusetts. He has also served as ongoing consultant to various special libraries including the Masonic Medical Research Foundation, Utica, New York.

A graduate of Syracuse University, Mr. Crowley received the A.B., M.A., and M.S.L.S. degrees from that institution. He has contributed poetry to numerous literary magazines including Poetry, Colorado Quarterly, Approach, Yankee, Canadian Forum, and Fiddlehead.

William Weiss, a catalog librarian at Milne Library, will assist Mr. Crowley as associate editor of the News.

News itams for inclusion in C\&RL News should be sent to Mary Frances Collins, Assistant Director of Libraries for Technical Services, University Library ULB-35A, State University of New York at Albany. I 400 Washington Ave. Albany, NY 12222. Advertising (including elassified ads) should be sent to Leona Swiech, Advertising Ollice, American Library Association, $50 \mathrm{E}$. Huron St., Chicago, IL 60611 . Production and circulation matters are handled by ALA Central Production Unit, at the above address.

News editor: Mary Frances Collins, Assistant Director of Libraries lor Technical Services, State University of New York at Albany, Albany. Editor: Richard D. Johnson, Milne Library, State University College, Oneonta, New York 13820. President ACRL: Connie R. Dunlap. Executive Secretary, ACRL: Beverly P. Lynch.

College \& Research Libraries is published by the Association of College and Research Libraries, a division of the American Library Association, 17 times yearly-6 bimonthly journal issues and II monthly (combining July-August) News issues-at |20|-05 Blufl St. Fulton, MO 6525l. Subscription, $\$ 15.00$ a year or to members of the division $\$ 7.50$, included in dues. Second-class postage paid af Fulton, Missouri 65251.

(C) American Library Association 1976. All material in this journal subject to copyright by the American Library Association may be photocopied for the noncommercial purpose ol scientific or educational advancement. 